\title{
A decade of REDD+ in a changing political environment in the Democratic Republic of Congo
}

\author{
Félicien Kengoum, Pham Thu Thuy and Denis Jean Sonwa
}

\section{Key messages}

- The REDD+ policy process in the Democratic Republic of Congo (DRC) over the past decade has diverged from the initial government planning due to political changes at the international and national levels.

- While participation is perceived by government and international actors as one of the biggest achievements of REDD+ in the DRC, non-state actors - particularly civil society organizations and Indigenous groups - are skeptical about inclusiveness within the decision-making process. Social inequalities and local power relations may hinder the implementation of participation instruments and the involvement of local and Indigenous communities, impeding their ability to achieve reduced deforestation and poverty alleviation.

- The political economy and the lack of data on deforestation and forest degradation - and on the recently discovered large swamp in the DRC - make it challenging to monitor, report and verify a reduction in forest emissions within a multilevel setting. The experience of REDD+ tested at scale in the DRC through the Mai-Ndombe jurisdictional project highlights the cost challenges of generating timely and accurate data.

- Supporting REDD+ finance in the DRC is difficult since the country relies entirely on international funding to fight climate change. A benefits-sharing mechanism remains unclear. Consequently, there is a lack of flexibility in addressing unanticipated costs that may result from the implementation of the process. This jeopardizes the success of the process and raises uncertainty about the expected results.

- Emerging issues, such as community forestry and the discovery of large swamp areas, make the DRC more attractive for the REDD+ program. The first issue offers a workaround to the problem of securing communal rights, while the second issue provides additional opportunities for REDD+ activities.

\section{Introduction}

Forests play a key role in the global efforts to fight climate change (IPCC 2019). Reducing forest cover loss could lower global $\mathrm{CO} 2$ emissions by as much as 5.8 billion tons each year, making countries with high levels of forest cover particularly relevant. The Democratic Republic of Congo (DRC) is 2,345,409 $\mathrm{km}^{2}$ in size and shares more than $10,000 \mathrm{~km}$ of border with nine neighboring countries (see Figure 1). According to the latest figures of the World Bank (2020), the DRC had a population of 86,790,567 inhabitants in 2019. The poverty rate in the DRC is $72 \%$ (World Bank 2018). Poor people mainly dwell in rural areas and rely on the exploitation of land and natural resources to sustain livelihoods (Mpoyi et al. 2013). The consensus is that forest cover, as reported in the country's nationally determined contributions on climate change, amounts to 152 million ha (MEDD 2015). The DRC has the largest and most well-conserved forests in the Congo Basin. However, the deforestation rate in the DRC for the period 2000-2015 is estimated at 0.2\% to 0.3\% per year (Kengoum et al. 2020) due to commercial agricultural production (40\%), food agriculture (20\%) and firewood (20\%) (MEDD 2015). The deforestation rate is among the highest in the Congo Basin region. The carbon sequestration potential of DRC forests for 2019 was estimated at 1,326 Mt CO2e (MEDD 2018). This was before large areas of swamp - mostly covered by oil, gas, timber and oil palm development concessions - were discovered in the country (Dargie et al. 2017; Miles et al. 2017). This makes the DRC a key candidate for international efforts to fight climate change through the mechanism of reducing emissions from deforestation and forest degradation in developing countries (REDD+), including forest conservation, sustainable forest management, and the enhancement of forest carbon stocks.

The DRC has been involved in REDD+ since 2009. The national REDD+ framework strategy aims to stabilize - from 2030 onwards - and maintain forest cover on $63.5 \%$ of the DRC's territory, thus reducing projected forest emissions by $56 \%$ in the period 2013-2030, while increasing gross domestic 


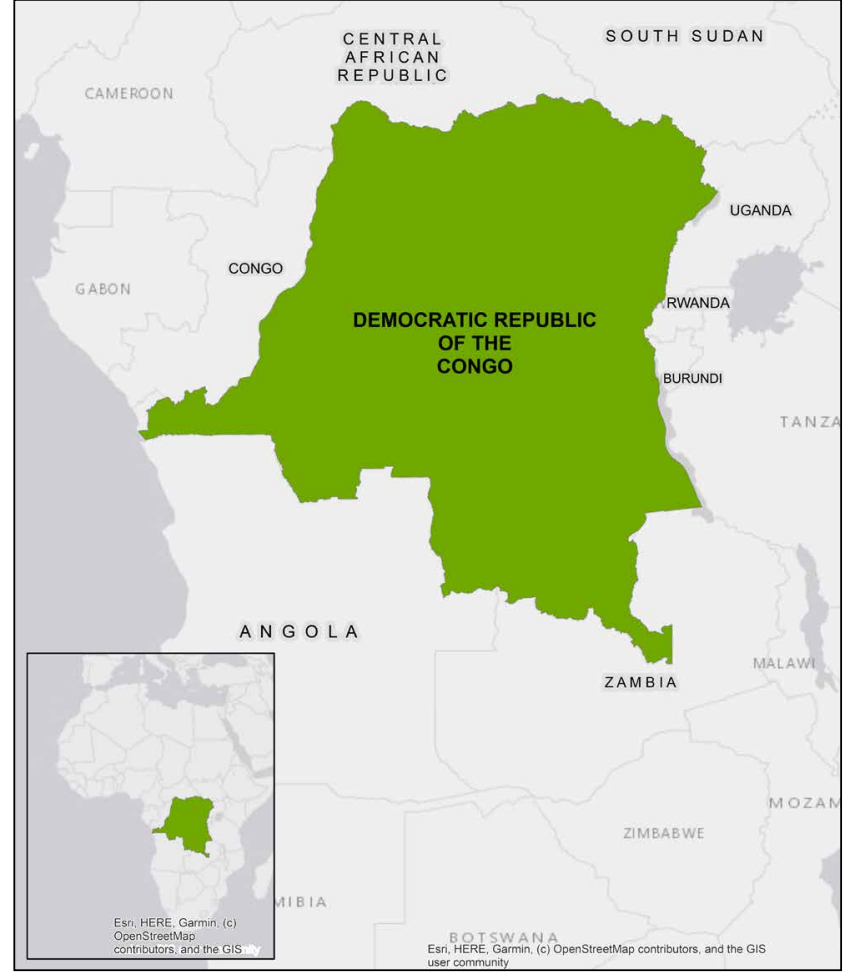

Figure 1. DRC in the Congo Basin.

product and alleviating poverty through seven strategic pillars, as presented in Figure 2. However, from 2009 to 2020, the country underwent various political changes and administrative decentralization, and there has been limited analysis on how REDD+ has evolved over time in this context. This infobrief analyzes REDD+ policies and progress in the DRC from 2009 to 2020, discussing opportunities, challenges and policy recommendations to promote effective, efficient and equitable outcomes for REDD+ activities. This analysis is based on the results of research project conducted by the Center for International Forestry Research (CIFOR) from 2017 to 2020 within the framework of the Global Comparative Study on REDD+ project (GCS-REDD+). The resulting report and publications (Kengoum 2020; Kengoum et al. 2020; Thuy et al. In press) are based on literature review, stakeholder interviews with 45 organizations and nine experts on REDD+, as well as data collected in the field. Useful information was also gained from a knowledge-sharing event on REDD+ and a capacity-building forum with journalists - both held in Kinshasa in October 2019 - as well as a webinar (71 attendees) in November 2020.

\section{Evolution of REDD+: An unachieved decade}

The DRC planned REDD+ through a four-phase process over the period 2009-2016 (see Figure 3). The country signed the official decree to engage in REDD+ in 2009. In 2012, it signed the Ministerial Homologation Decree for REDD+ projects and programs, then created the National REDD+ Fund (FONAREDD) and ultimately became the first in the Congo Basin to have its National REDD+ Framework Strategy validated in the same year (Mpoyi et al. 2013). In 2015, the Central African Forest Initiative (CAFI) was launched;

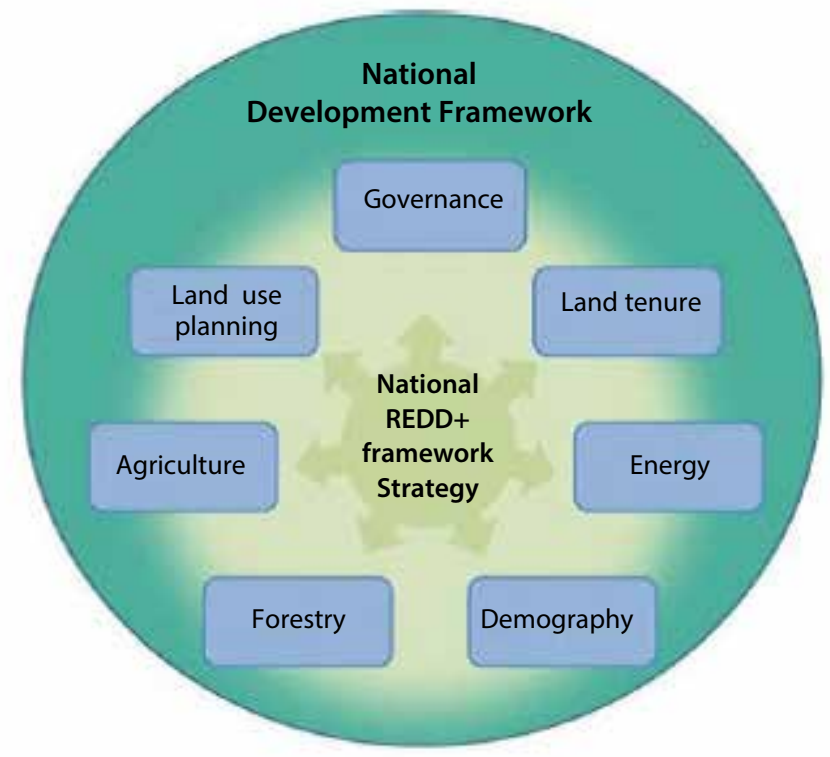

Figure 2. The seven pillars of the REDD+ framework strategy in the DRC.

Source: DRC, 2012

the REDD+ Investment Plan was validated; the intended nationally determined contributions were submitted to the United Nations Framework Convention on Climate Change (UNFCCC), and the Paris Agreement was signed by the DRC government. REDD+ did not develop according to the original plan, as outlined in Figure 3, and it was only in 2017 that the country engaged in participatory discussions on the REDD+ national benefit-sharing mechanism - on which there was still no national agreement in 2020. After a decade of efforts, only 20\% of the initial budget of USD 1 billion has been raised through the $\mathrm{CAFI}$, as highlighted by the national REDD+ coordinator in a recent interview granted to CIFOR (Ngeunga 2020). These delays have raised a lot of concerns among actors both in the national and international REDD+ community, who regularly presented the DRC as a REDD+ role model in the Congo Basin. Analysts even concluded that the DRC had lost this position as its REDD+ projects do not show a capacity to achieve the expected reduction in emissions (Seyller et al. 2016). Brockhaus, cited by Vander Velde and Furnival (2014) and later Streck (2019), concluded that - contrary to expectations - REDD+ is not a quick, easy and cheap mechanism. Many factors have contributed to delaying the full implementation of tasks needed to complete each stage of the process (Kabengele 2017). The question is then how policymakers can adapt to this fast-changing environment in order to ensure that current achievements are maintained, and REDD+ objectives are met in forthcoming phases. Understanding what factors facilitate and hinder the development and implementation of REDD+ will also be key to mitigating the problem.

\section{REDD+ successes and challenges in the DRC}

REDD+ in the DRC is well embedded in existing climatechange agreements that the country has signed. The DRC has signed 29 international conventions on the environment, 


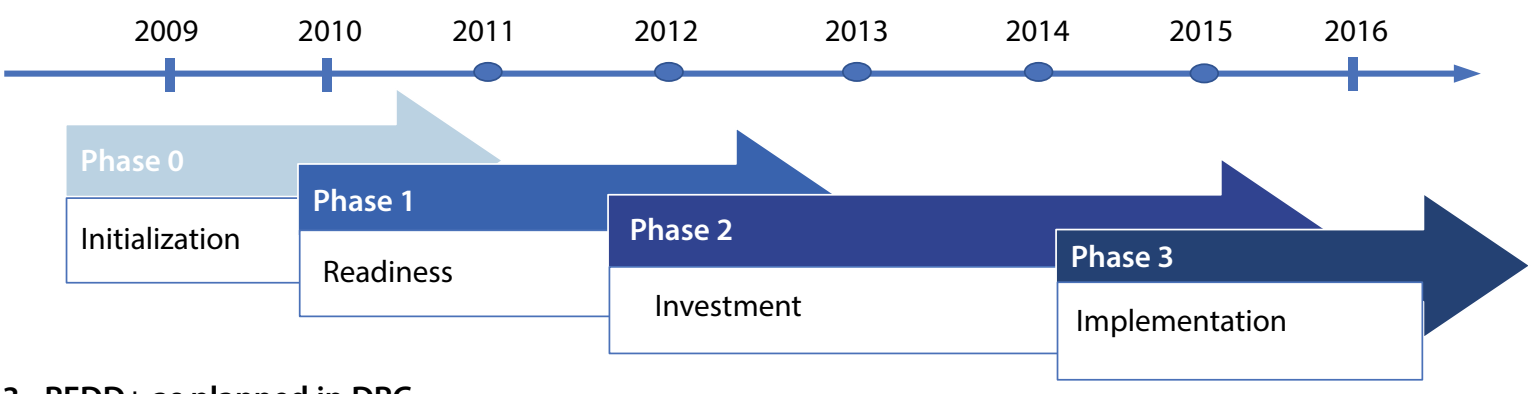

Figure 3. REDD+ as planned in DRC.

Source: Kengoum et al., 2020

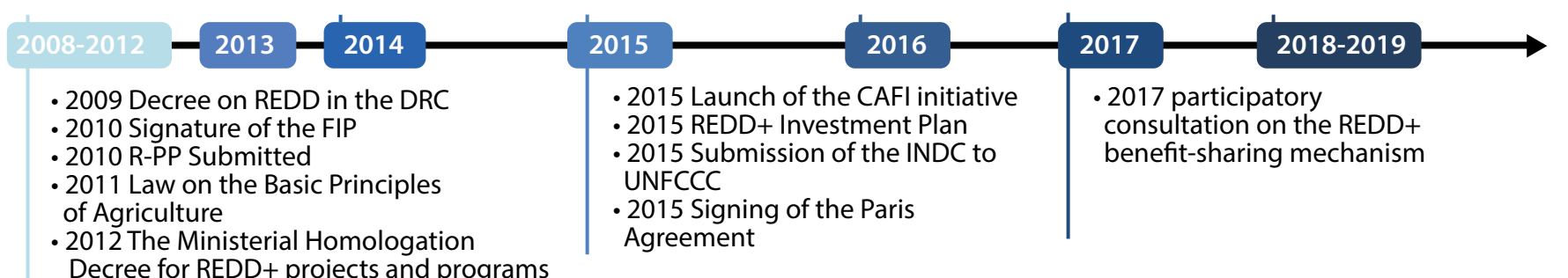

- 2012 Creation of the National REDD+ Fund

- 2012 National REDD+ Framework Strategy

Figure 4. REDD+ political development in DRC.

Source: Adapted from Kengoum et al., 2020

natural resources and the fight against climate change. In its nationally determined contributions submitted to the UNFCCC within the framework of the Paris Agreement, the DRC committed itself to a $17 \%$ reduction in its emissions by 2030 (MEDD 2015). The country has tried to put in place datacollection bodies - such as a national meteorological agency, an agronomical institute (INERA), a waterways authority (RVF) and a maritime management agency (RVM) - to monitor climate change and to provide climate information. The DRC has also implemented an adaptation project (PANA/ ASA), but Kengoum et al. (2020) pointed out that this has not made much progress so far. The national government has also committed itself to internalizing the costs of fighting climate change as much as possible, to prioritizing existing bilateral funding mechanisms, and to improving national climate governance through the European Union's VPA-FLEGT process, involving voluntary partnership agreements on the trade of harvested timber (Kengoum et al. 2020).

The following sections will analyze the opportunities and challenges for REDD+ development in the DRC, covering several dimensions of the mechanism.

\section{Actors, institutions and participation in REDD+}

The REDD+ governance in the DRC is overseen by the National REDD+ Committee created by Decree No. 09/40 of 26 November 2009. It involves almost 20 ministries and is led by the Ministry of Environment and Sustainable Development. The national REDD+ coordination unit within this ministry manages daily REDD+ activities. It is the interlocutor of the REDD Climate Working Group (GTCR-R) and the Network of Indigenous Peoples and Local Communities for the Sustainable Management of Forest Ecosystems (REPALEF) in the DRC, as the main groups representing more than 500 national organizations participating in REDD+. All these actors are part of the 30 thematic groups created as multistakeholder platforms to discuss and propose measures to equitably achieve REDD+ objectives. Several international actors - such as the World Wildlife Fund, the World Resources Institute, the Center of Excellence for Forest Monitoring by Remote Sensing (OSFAC), the Japan International Cooperation Agency (JIC), the Japan Forest Technology Association (JAFTA) and CIFOR - as well as certain private companies are working on REDD+ projects. Some of the international actors are based in the DRC, while others work remotely from abroad, in provinces and on REDD+ project sites (Thuy et al. In press).

There has been increasing involvement of actors in REDD+ policy events in the DRC since 2009, mainly due to conditions set out by the UN-REDD Programme and the Forest Carbon Partnership Facility, which stipulate that REDD+ operate as a participatory process. Financial support - including that within the CAFI framework - also boosted participation, helping civil society organizations to organize themselves and start building their REDD+ capacities (Kengoum et al. 2020). This has led to improved relations between government and civil society organizations (Thuy et al. In press).

Participation in REDD+ is perceived at the national level as one of the most significant outcomes of the policy process in the DRC (Fobissie et al. 2014; Mpoyi et al. 2013; Kengoum et al. 2020, Thuy et al. In press). However, at local level, REDD+ social safeguard guidelines might be difficult to achieve if social inequalities and local power relations are not acknowledged and addressed in the implementation of REDD+, as is the case in REDD+ pilot areas in the DRC (Samndong 2018). Self-forming civil society organizations have been encouraged by international donors, and even 
been proposed as a condition for the validation of the national process outputs. The donor requirements have facilitated the sharing of good practices and strengthened the ability of stakeholders to respond to unanticipated events through innovation (Bizikova et al. 2018). However, civil society organizations, when interviewed, were skeptical about inclusiveness in the decision-making process as their role is still limited.

Coordination between ministries has been an issue since the beginning of the process due to many factors, including the fragmentation of the policy institutional framework (Eba'a Atyi et al. 2018), and the political arrangement of the government architecture that led to power plays among ministries and weak national ownership of the process (Mpoyi et al. 2013; Kalame et al. 2014; Kengoum 2015; Kengoum et al. 2020; Thuy et al. In press). Funding for the national REDD+ coordination unit has fallen by more that 70\% since December 2016, causing a serious impact on its capacity to oversee REDD+.

The coordination of policy reforms to meet REDD+ objectives was announced as one of the key governance outputs in the national REDD+ strategy. The country thus started the forest law reform and the agriculture policy reforms. The ongoing land-tenure reform and the design of a national land-use plan are supported by the CAFI funds to the tune of USD 3 million and USD 14 million, implemented by UN-Habitat and the United Nations Development Programme, respectively. Among reforms in the forest sector, there was a debate about conditions for retaining or lifting the moratorium on the attribution of new forest concessions. To date, none of these reforms has been completed. Their processes are not coordinated and there are still risks that the outputs - even though they integrate REDD+ - won't be coherent one with the other Therefore, land insecurity persists in the DRC (Kengoum et al. 2020).

\section{Decentralization of REDD+ governance}

According to Article 13 of Decree N09/40 from 26 November 2009, REDD+ implementation structures will be created at the level of the provinces, and of the decentralized and deconcentrated territorial entities (see Figure 5), whose composition and organization will follow those of the national structure. The decentralization of the national REDD+ coordination unit follows this pattern, as shown in Figure 6, with each REDD+ province being appointed a coordinator. The country has experienced radical change in political and administrative decentralization. The Constitution, adopted on 18 February 2006, led to three decrees: (i) Law No. 08/012 of 31 July 2008 on the fundamental principles for the free administration of provinces; (ii) Law No. 08/015 of 7 October 2008 laying down rules for the organization and functioning of the Conference of Provincial Governors; and (iii) Law No. 08/016 of 7 October 2008 on the composition, organization and functioning of decentralized territorial entities and their relationship with the State and the province. This decentralization framework has been effective since 2016 (Luntumbue 2016) and, consequently, the country shifted from 11 to 26 provinces. As highlighted by Luntumbue (2016), this reform was initiated without considering the new financing needs. Therefore, the new provinces' autonomy has not been effective in many provinces so far. For this reason, the establishment of REDD+ institutions in these new provinces might be delayed for months or years, and it will take time for new provincial institutions to become effective (Kengoum et al.2020). In the same way, the distribution of some ongoing REDD+ initiatives between two new provinces will require adaptability of the system to cope with the involvement of different competent administrative units on the same project, and the tensions that might result from the new distribution (Makal 2014). Beyond this, the decentralization process of REDD+ started in its early years in the DRC. However, with the above-mentioned budget cuts affecting the national REDD+ coordination, the existing decentralized REDD+ coordination units can no longer operate. In a recent interview reported by CIFOR, the national REDD+ coordinator said the following: "We intend to revitalize the technical coordination of actions at the national level and revitalize the bodies in charge of implementing the REDD+ process in the DRC, or update them if necessary."

REDD+ in the DRC has been largely centralized in institutions based in Kinshasa, the national capital (Mpoyi et al. 2013). The country is landlocked and there is an important administrative fragmentation between Kinshasa and the various provinces (Brandt and Moshonas 2019; Kengoum et al. 2020). Therefore, managing local issues from Kinshasa is a real challenge. Promoting subsidiarity, not only in implementation but in policymaking, is key to ensuring that the decision-making process is not fully impacted when it is blocked at the national level. Similarly, national authorities sometimes aren't aware of problems that happen at the local level, and can't propose interventions at the right decision-making level. In its current model, REDD+ policymaking in the DRC uses a top-down approach. Defining the lowest level of effective and accountable governance unit in REDD+ within the policymaking process remains a challenge as the country does not have the same administrative structure from one province to another. In certain provinces, there are no decentralized units of the ministry in charge of the environment. Therefore, the responsibility of managing climate change may fall under a different ministry that is not in charge of forestry and the environment at a national level. There is a reason for this: Since the end of the transitional government in 2006, some parties have held the same ministerial portfolios because they are distributed based on the criterion of belonging to the ruling coalition (Kengoum 2015). In any case, depending on the legal profile of the sub-level REDD+ coordination unit, it can operate within a specific ministry, while interacting with the national REDD+ coordination.

\section{Monitoring, reporting and verification of REDD+ in a complex multiple-level setting}

The knowledge and data on forest-cover dynamics in the DRC are limited. Kengoum et al. (2020) show that there are several estimates of both forest cover and deforestation loss, but no study has provided information about deforestation nationwide using the same methodology. The REDD+ Forest Reference Emissions Level (FREL) document also confirmed that data on forest degradation are also lacking. This is why "the DRC has decided to focus its first FREL on deforestation, the activity for which data are available, transparent and reliable" (DRC 2018). A review was conducted in 2017 to decide which operational options are suitable for the development of allometric equations for REDD+. It confirmed the difficulty of carrying out a systematic study due to the varieties of forest 


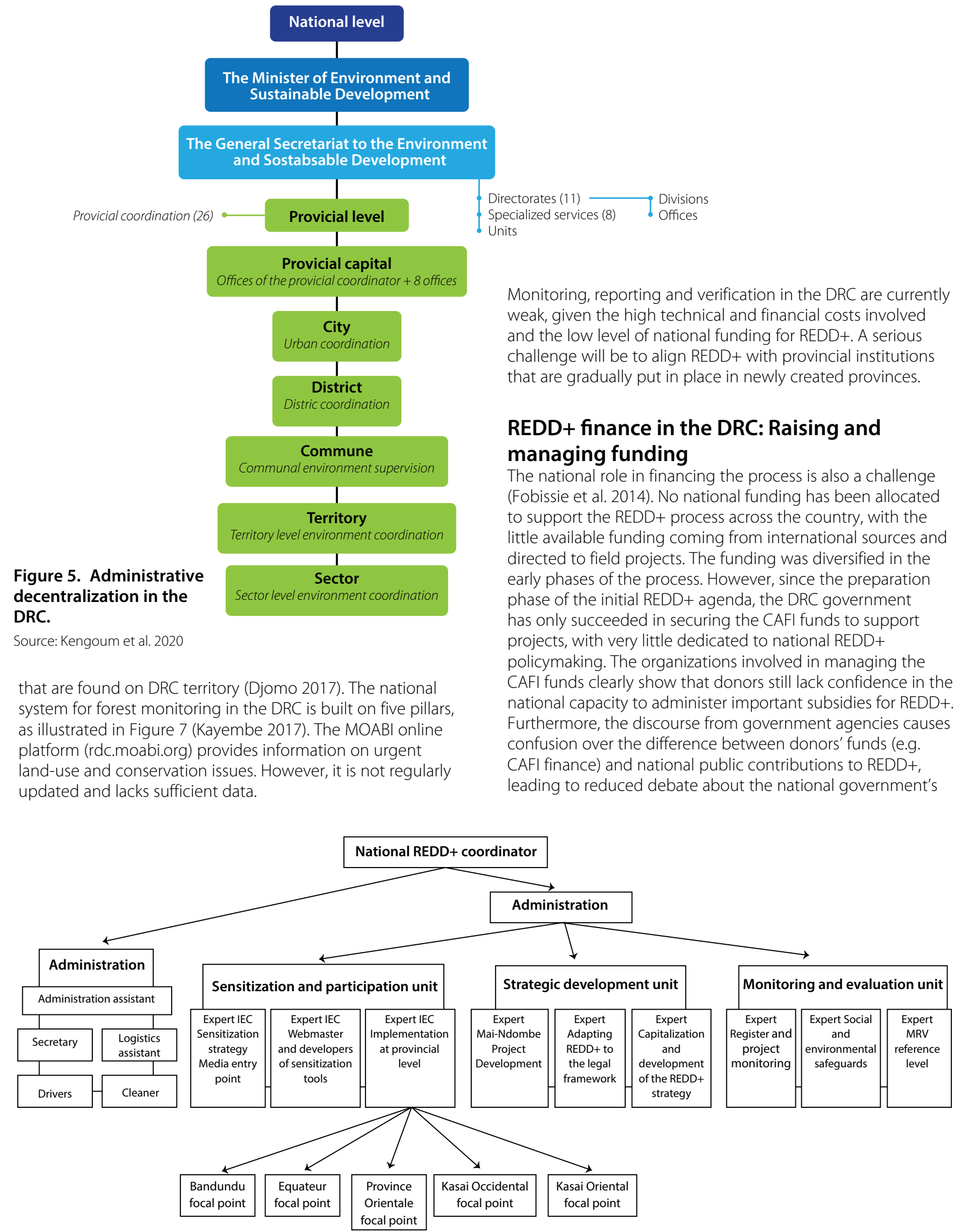

Figure 6. Decentralization of REDD+ management in the DRC.

Source: DRC, 2012 


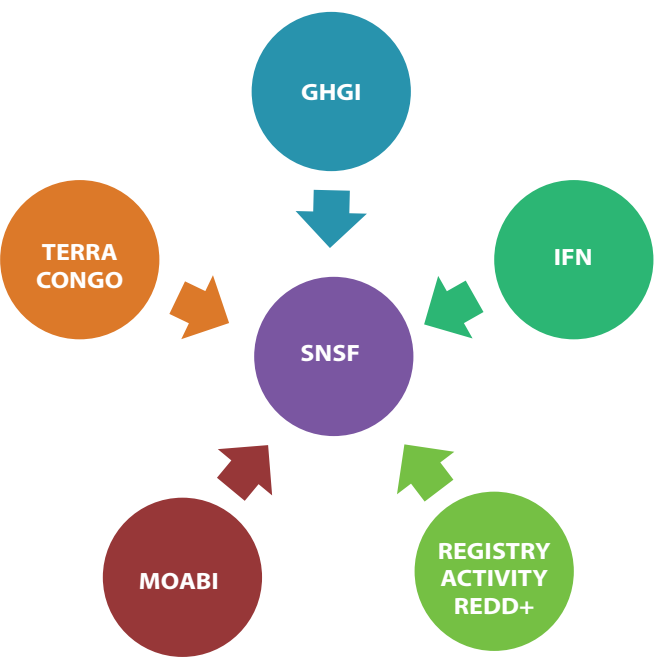

Figure 7. MRV pillars in the DRC.

Source: Kayembe, 2017

funding for REDD+. The CAFI funding, whose management is overseen by the National REDD+ Fund, supports eight integrated REDD+ projects in the provinces of Mai Ndombe, Kwilu, South Ubangi, Équateur, Mongala, Bas-Uélé, Tshopo and Ituri (FONAREDD 2018). It does not include support for the national REDD+ coordination unit, which is lacking minimum resources to operate.

\section{Community forestry and REDD+: An emerging issue}

REDD+ in the DRC has not granted land and natural resource rights to local communities and Indigenous peoples. Today, communities enter the forestry sector in the DRC through community forestry. The prime minister's Decree No. 14/1018 of 2 August 2014 defined a system for allocating forest concessions to local communities. It was followed by Ministerial Order 025, which included specific provisions relating to the management and operation of local communities' forest concessions. This development led to a decree on community forestry (signed in 2016), including a ministerial circular on the mainstreaming of gender in community forestry before a final roundtable took place in August 2017. The national strategy for community forestry and a five-year action plan were then validated in 2017. The ministerial order creating provincial forest advisory councils and a committee for local communities' forest concessions became effective in 2018. Consequently, local community members - who are allocated the forests for a lifetime - gain a legal right to their land, so they can decide whether to join a REDD+ program and receive related payments. However, as highlighted by participants during a CIFOR knowledge-sharing event in Kinshasa in October 2019, the DRC government has focussed on communities' access to forests while neglecting the work required to build their capacities to manage those forests (Kengoum et al. 2019). The risk today is that these communities may turn to private companies to exploit their forests and provide direct rewards in return.

\section{Making REDD+ work at local level: Lessons from the Mai-Ndombe jurisdictional project}

The Mai-Ndombe forest hosts many local communities and Indigenous peoples (Omasombo Tshonda 2019). It has rich biodiversity and provides local communities with the services of several ecosystems. The forest acts as a carbon sink and a buffer zone against floods (Kantu 2009). The Mai-Ndombe hosts three protected areas and about 20 forestry concessions. Given the country's increasing population and the forest's supply of charcoal, nontimber products, bushmeat and livestock to the nearby province of Kinshasa, Mai-Ndombe has become a deforestation hotspot in the DRC. As a result, the World Bank selected it for a REDD+ jurisdictional program embedded in the national REDD+ process (Diaw and Franks 2019). The transformational effects expected from the program are fourfold (DRC 2016) - (i) improved governance verified by the inclusion of deforestation in the local and provincial investment plans and land-use political decisions; and the more effective management of land use-related conflicts; (ii) communities and entrepreneurs should adopt the rationale of low-level deforestation defined by the agreed development plan drawn up in a participatory manner; (iii) farmers should improve their agricultural practices in the long term, orienting their productive activities toward savannas and accepting restrictions on the use of forests; and (iv) the formalization of commodity sectors with better legal controls and fewer impacts on forest cover, while benefiting the population with guaranteed outlets for their products at stable prices.

The implementation of the Mai-Ndombe REDD+ project raises much debate about its additionality (REDD-Monitor 2017); its capacity to pave the way for a different kind of conversation about smallholder agriculture and its relationship with deforestation and biodiversity loss (Diaw and Franks 2019); and its effectiveness in benefiting Indigenous peoples and local communities (Gauthier 2018). The major barriers to REDD+ - as identified in the Mai-Ndombe area - is the incapacity of governmental and nongovernmental actors, including the private sector, to develop financially viable and competitive alternatives to deforestation and forest degradation. The reasons behind these difficulties are poverty; a lack of upfront financing, incentives and knowledge transfer; a weak business climate that remains rather unattractive; land tenure insecurity; poor governance; and a lack of institutional capacity (FCPF 2016). Gauthier (2018) highlighted five issues that remain unaddressed in 2020, despite efforts by project stakeholders and ongoing policy reforms. The first is the REDD+ governance architecture, which is still fragile because of inadequate decentralized structures and an inconsistency in applying existing safeguard instruments, leading to a high risk of corruption, as discussed earlier by Assembe (2015). The second concern is related to the points made by Diaw and Franks (2019) about insufficient knowledge regarding the local drivers of deforestation. No study on the drivers of deforestation and forest degradation at the provincial level has been carried out to build a consensus, leading to differing opinions on who to blame for deforestation and how to 
address the real causes. The third issue is the inadequate participation of Indigenous peoples and local communities - as right holders - in the project's decision-making process, with the application of the Free, Prior and Informed Consent principle being only partially effective. Therefore, efforts to address land-tenure insecurity remain limited. The opportunity arising from the implementation of community forestry is not being exploited in the Mai-Ndombe project to secure communities' rights to access forest land and resources. Local communities are therefore unable to benefit from REDD+ payments since there is no agreement on a benefit-sharing mechanism yet. The price of carbon is also an important concern for project stakeholders as the cost per ton on the international market provides little incentive - with the exception of the agreement with the World Bank to purchase 10 million tons CO2eq over five years.

\section{Conclusion}

REDD+ is not an easy, quick and cheap process, even in countries with strong potential, such as the DRC. The decade of REDD+ development in the DRC demonstrated the tendency observed by Angelsen et al. (2018), who concluded that REDD+ has not granted tenure rights to Indigenous and local communities so far and therefore its innovative resultsbased payments have largely gone untested amid a scarcity of international funding and market demand to support ongoing project efforts. Political developments in the DRC also complicate REDD+ implementation. As suggested by Diaw and Franks (2019), decision makers will need to be flexible in order to build the DRC's strategic and adaptive capacity as well as the country's REDD+ governance and institutions.

\section{References}

Angelsen A, Martius C, Duchelle AE, Larson AM, Pham $T$ and Wunder S. 2018. Conclusions: Lessons for the path to a transformational REDD+. In Angelsen A, Martius C, De Sy $V$, Duchelle AE, Larson AM and Pham TT, eds. Transforming REDD+: Lessons and new directions. Bogor, Indonesia: CIFOR. 203-214.

Assembe-Mvondo S. 2015. National-level corruption risks and mitigation strategies in the implementation of REDD+ in the Democratic Republic of the Congo: An overview of the current situation. Bergen, Norway: Chr.Michelsen Institute. 9

Bizikova L, Swanson D, Tyler S, Roy D and Venema HD. 2018. Policy adaptability in practice. Policy Design and Practice 1(1):47-62. doi:10.1080/25741292.2018.1436376

Brandt C and Moshonas S. 2019. L'impact de la décentralisation sur la gouvernance du système éducatif en République démocratique du Congo: Entre contraintes budgétaires et fragmentation administrative. In : Englebert, P\& Ngoy, B (eds) : Congo : L'Etaten morceaux. Politique et administration au prisme du découpage provincial, Tervuren : MRAC

Dargie GC, Lewis SL, Lawson IT, Mitchard ETA, Page SE, Bocko YE and Ifo SA. 2017. Age, extent and carbon storage of the central Congo Basin peatland complex. Nature 542(7639):86-90. doi:10.1038/nature21048
Diaw MD and Franks P. 2019. Production alimentaire, expansion agricole et déforestation au Mai-Ndombe, RDC. IIED document de travail. London : IIED. https://pubs.iied. org/pdfs/17652IIED.pdf

Djomo A. 2017. REDD+en RDC: Etat des lieux et options opérationnelles pour le développement des équations allométriques. Ministre d'Environnement et Développement Durable (MEDD).

DRC, 2016. Summary: Mai Ndombe Emission Reduction Program, DRC.

Eba'a Atyi R. (cord.) Contributions of Central African countries to combat climate change: The urgent need for intersectorial coordination. OFAC Brief. Series n². Nov 2018.

[FCPF] Forest Carbon Partnership Facility: The Carbon Fund. 2016. Emission Reductions Program Document (ER-PD). MaiNdombe. Final.

Fobissie K, Alemagi D and Minang PA. 2014. REDD+ policy approaches in the Congo basin: A comparative analysis of Cameroon and the Democratic Republic of Congo (DRC). Forests 5(10):2400-2424.

[FONAREDD] REDD+ National Fund. 2018. Présentation du FONAREDD. Kinshasa, DRC: FONAREDD. http://www. fonaredd-rdc.org/presentation-du-fonaredd/.

Gauthier M. 2018. Mai-Ndombe: Will the REDD+ laboratory benefit indigenous peoples and local communities? Analysis of the cumulative impacts and risks of REDD+ initiatives. Washington, DC: Rights and Resources Initiative.

[IPCC] Intergovernmental Panel on Climate Change. 2019. Summary for policymakers of IPCC special report on global warming of $1.5^{\circ} \mathrm{C}$. Working Group I Technical Support Unit, IPCC.

Kabengele V. 2017. Etat d'avancement du processus national REDD+ en RDC: De la phase de préparation à la phase de paiements basés sur les résultats. Personal communication, IITA Journalist Capacity Building Workshop, 28 August 2017. Kinshasa.

Kayembe F. 2017. La REDD+ et ces enjeux actuels en RDC: MRV. Personal communication, IITA Journalist Capacity Building Workshop, 29 August 2017. Kinshasa.

Fobissie K, Alemagi D and Minang PA.2014. REDD+ policy approaches in the Congo basin: A comparative analysis of Cameroon and the Democratic Republic of Congo (DRC). Forests 5(10):2400-2424. https://doi.org/10.3390/f5102400.

Luntumbue M. 2016. RDC: Les enjeux du redécoupage territorial: Décentralisation, équilibre des pouvoirs, calculs électoraux et risques sécuritaires. Les rapports du GRIP 2016/10. https://grip.org/product/rdc-les-enjeux-duredecoupage-territorialdecentralisation-equilibres-despouvoirscalculs-electoraux-et-risques-securitaires/

Kantu YPT. 2009. Congo Basin, DRC: Case study on the NgiriTumba - Mai-Ndombe Wetland Landscape. Environmental Security Assessment. The Hague, Netherlands: Institute for Environmental Security.

Kengoum F. 2015. Adaptation policies and synergies with REDD+ in Democratic Republic of Congo: Context, challenges, and perspectives. Occasional Paper 135. Bogor, Indonesia: CIFOR.

Kengoum F., Thu Thuy, P., Dwi Satrio B., Sonwa, D., Assan H., Bambuta Boole, J.J. 2019. REDD+ politics and policies in DRC: Knowledge sharing event and field trip Kinshasa 16 and 17 October 2019. Unpublished Report. 
Kengoum F, Pham T, Moeliono M, Dwisatrio B and Sonwa DJ. 2020. The context of REDD+ in the Democratic Republic of Congo: Drivers, agents and institutions. 2nd edition. Occasional Paper 207. Bogor, Indonesia: CIFOR. doi:10.17528/cifor/007793

Kengoum F. 2020. REDD+ policy netswosrks in DRC: Stances, perceived influence, collaboration, and coalitions. CIFOR. GCS-REDD+ projects. Unpublished report.

Martinez de Anguita P, Martín MÁ and Clare A. 2014. Environmental subsidiarity as a guiding principle for forestry governance: Application to payment for ecosystem services and REDD+ architecture. Journal of Agricultural and Environmental Ethics 27(4):617-631. https://doi.org/10.1007/ s10806-013-9481-8

Makal D. 2014. Découpage territorial en RDC: Kolwezi risque de tuer! Lubumbashi, DRC: Tout Lubumbashi. Accessed 14 August 2020. https://toutlubumbashi.blogspot. com/2014/12/decoupage-territorial-en-rdckolwezi.html.

Miles L, Ravilious C, García-Rangel S, de Lamo X, Dargie G and Lewis S. 2017. Carbon, biodiversity and land-use in the Central Congo Basin Peatlands. Cambridge, UK: UN Environment World Conservation Monitoring Centre.

[MEDD] Ministère de l'Environnement et Développement Durable. 2015. Contribution prévue et déterminée au niveau national. Soumises à la CCNUCC. Kinshasa: MEDD.

[MEDD] Ministère de l'Environnement et Développement Durable. 2018. Niveau d'émissions de référence des forêts pour la réduction des émissions dues à la déforestation en République Démocratique du Congo: Soumission à la CCNUCC. Kinshasa: MEDD. https://redd.unfccc.int/files/2018_frel_ submission_drc.pdf

Mpoyi AM, Nyamwoga FB, Kabamba FM and AssembeMvondo S. 2013. The context of REDD+ in the Democratic Republic of Congo: Drivers: Agents and institutions. Occasional Paper 94. Bogor, Indonesia: CIFOR. doi:10.17528/ cifor/004267

Ngeunga M. 2020. Coordonner les actions pour garantir le succès de la REDD+ en RDC : Un regard sur la mise en œuvre dix ans après. CIFOR Blog. https://forestsnews.cifor. org/69710/coordonner-les-actions-pour-garantir-le-succesde-la-redd-en-rdc?fnl=en (Consulté le 20 Novembre 2020)

Omasombo Tshonda J. 2019. Mai-Ndombe: Mosaïque de peuples étalie sur un patrimoine naturel. Tervuren, Belgium: Musée Royal de l'Afrique centrale.

RDC, 2012, Stratégie nationale cadre REDD+. https://www. forestcarbonpartnership.org/system/files/documents/ Strategie-cadre\%20nationale\%20REDD\%20de\%20la\%20 RDC.pdf

REDD-Monitor, 2017. Is Wildlife Work's Mai Ndombe REDD+ project 'additional'? Accessed 21 December 2020. https:// redd-monitor.org/2017/09/13/is-wildlife-works-maindombe-redd-project-additional

Samndong RA. 2018. The participation illusion: Questioning community participation in a REDD+ pilot project in the Democratic Republic of Congo. International Forestry Review 20(3):390-404.

Seyller C, Desbureaux S, Ongolo S, Karsenty A, Simonet G, Faure J and Brimont L. 2016. The 'virtual economy' of REDD+ projects: Does private certification of REDD+ projects ensure their environmental integrity? International Forestry Review 18(2):231-246.

Streck C. 2019. Shades of REDD+: A Marshall plan for tropical forests? Ecosystem Marketplace https://www. ecosystemmarketplace.com/articles/shades-of-redd-amarshall-plan-for-tropical-forests/

Thuy and al. (In Press) REDD+ governance in DRC- An analysis from actors' participation in REDD+ policy development. International forestry review.

Vander Velde B and Furnival S. 2014. 'Honeymoon' over, REDD+ struggles with politics and power. Forests News. Bogor, Indonesia: CIFOR. https://forestsnews.cifor. org/25197/redd-policy-politics-power-brockhaus?fnl=

World Bank. 2020. Population, total - Congo, Dem. Rep. Accessed 20 December 2020. https://data.worldbank.org/ indicator/SP.POP.TOTL?locations=CD

\begin{tabular}{|l|l} 
RESEARCH \\
PROGRAM ON \\
Forests, Trees and \\
Agroforestry
\end{tabular}

This research was carried out by CIFOR-ICRAF as part of the CGIAR Research Program on Forests, Trees and Agroforestry (FTA). FTA is the world's largest research for development program to enhance the role of forests, trees and agroforestry in sustainable development and food security and to address climate change. CIFOR leads FTA in partnership with Bioversity International, CATIE, CIRAD, INBAR, ICRAF and TBI. FTA's work is supported by the CGIAR Trust Fund: cgiar.org/funders/ 